\title{
Analisis Pengaruh Karat Sand Blasting Terhadap Laju Korosi Pelat Pontoon Floating Dock di Galangan Reparasi Kapal
}

\author{
Taufik Hidayat, Triwilaswandio Wuruk Pribadi, dan M. Sholikhan Arif \\ Departemen Teknik Perkapalan, Fakultas Teknologi Kelautan, \\ Institut Teknologi Sepuluh Nopember (ITS) \\ e-mail: triwilas@na.it.ac.id
}

\begin{abstract}
Abstrak-Reparasi kapal di atas floating dock, dilakukan proses sand blasting untuk membersihkan lambung kapal dari karat. Karat dan pasir sand blasting menumpuk menjadi material deposit di atas permukaan pelat pontoon floating dock. Tumpukan karat dan pasir sand blasting tidak dibersihkan secara menyeluruh sehingga mempengaruhi mekanisme korosi pelat pontoon floating dock yang memicu terjadinya korosi di bawah lapisan karat dan pasir sand blasting atau lebih dikenal sebagai korosi bawah deposit. Untuk mengetahui pengaruh dari karat dan pasir sand blasting terhadap laju korosi pelat pontoon floating dock, dilakukan pengujian laju korosi menggunakan metode elektrokimia dengan teknik polarisasi dimana permukaan spesimen tertutupi oleh material deposit karat sand blasting di dalam larutan $\mathrm{NaCl} 3,5 \%$. Variasi material deposit dalam pengujian ditentukan berdasarkan data hasil observasi lapangan berupa variasi komposisi pasir sand blasting dan karat yaitu $80 \%$ : $20 \%, 70 \%$ : $30 \%$, dan $60 \%: 40 \%$. Variasi ketebalan material deposit yaitu tebal $2 \mathrm{~cm}, 4 \mathrm{~cm}$, dan $6 \mathrm{~cm}$. Variasi permukaan pelat yang tertutupi material deposit yaitu $100 \%, 50 \%$, dan $30 \%$ permukaan dan pengujian tanpa material deposit sebagai benchmark. Berdasarkan hasil pengujian diketahui bahwa spesimen dengan permukaan tertutupi material deposit karat sand blasting mempunyai laju korosi yang lebih cepat dari pada spesimen yang tidak tertutupi material deposit dan semakin tebal material deposit maka laju korosinya semakin cepat. Semakin besar diferensial aerasi antara permukaan yang tertutupi material deposit dan permukaan yang tidak tertutupi material deposit karat sand blasting maka nilai laju korosi semakin besar. Selain itu, semakin banyak kandungan karat didalam material deposit karat sand blasting maka laju korosinya semakin cepat. Korosi yang disebabkan oleh material deposit karat sand blasting mengakibatkan penurunan keuntungan yang diperoleh floating dock dimana keuntungan terendah yaitu sebesar Rp4.285.627.040,00. Sedangkan keuntungan yang diperoleh pada kondisi permukaan pontoon floating dock tidak tertutupi material deposit adalah sebesar Rp13.439.792.320,00.
\end{abstract}

Kata Kunci-Deposit karat, Floating dock, Korosi.

\section{PENDAHULUAN}

F LOATING dock merupakan salah satu sarana pengedokan kapal yang memiliki kelebihan dalam hal kemudahan untuk pengedokan kapal karena dapat dipindahkan, diapungkan, dan ditenggelamkan sesuai kebutuhan pengedokan [1]. Namun sebagai bangunan konstruksi, flaoting dock memiliki kemungkinan mengalami kerusakan akibat korosi karena floating dock berada dalam lingkungan air laut yang memiliki kadar salinitas tinggi. Suatu baja mild steel ASTM A36 dimana baja jenis ini merupakan baja yang sering digunakan dalam industri perkapalan, ketika berada pada media larutan dengan kadar salinitas 33\% mempunyai tingkat ketahanan korosi sebesar 0,2139 milimeter per year. Namun, ketika kadar salinitas dalam media larutan bertambah menjadi 35\% menyebabkan tingkat ketahanan korosi pada baja ini berubah menjadi 0,4539 mmpy. Semakin tinggi kadar salinitas yang terkandung dalam air laut semakin besar nilai laju korosi yang terjadi [2].

Dalam pekerjaan reparasi kapal diatas floating dock, dilakukan kegiatan sand blasting untuk membersihkan lambung kapal dari karat, fouling, dan kotoran lain yang menempel pada lambung kapal. Namun, kegiatan sand blasting mengakibatkan pasir sand blasting dan karat menumpuk diatas pelat pontoon flaoting dock menjadi material deposit berupa karat sand blasting. Dalam waktu yang lama karat dan pasir sand blasting tidak dibersihkan seluruhnya dari pontoon floating dock sehingga pelat ponton masih tertutupi dengan material deposit dari campuran karat dan pasir sand blasting. Tumpukan material deposit karat sand blasting berada dalam kondisi basah karena terkena air yang berasal dari kapal maupun air yang berasal dari floating dock. Dalam kondisi ini, permukaan pelat pontoon floating dock mengalami korosi dibawah material deposit karat sand blasting dan jenis korosi ini dikenal sebagai Under Deposit Corrosion [3].

Fenomena korosi yang terjadi dibawah deposit karat sand blasting merupakan hal yang harus diwaspadai karena korosi ini terjadi dibawah material deposit dan tidak terlihat dari luar material deposit. Sementara, adanya material deposit diatas pelat ponton dapat mempengaruhi besar laju korosi yang terjadi pada pelat pontoon floating dock. Korosi bawah deposit dapat terjadi karena adanya perbedaan konsentrasi oksigen antara daerah dibawah material deposit dengan daerah diluar material deposit yang menyebabkan daerah dibawah material deposit mengalami penurunan $\mathrm{pH}$ sehingga tingkat keasaaman meningkat dan dapat mempercepat terjadinya korosi [4]. Hal ini dapat menimbulkan dampak negatif pada pelat pontoon floating dock yang dapat mengurangi ketebalan pelat dan menimbulkan kerusakan parah apabila tidak diperhatikan faktor yang mempengaruhinya.

Untuk mengetahui pengaruh material deposit karat sand blasting terhadap laju korosi yang terjadi pada pelat pontoon floating dock, dilakukan pengujian korosi menggunakan metode elektrokimia dengan teknik polarisasi.

\section{STUDI LITERATUR}

Korosi adalah kerusakan yang terjadi pada material yang 
disebabkan oleh reaksi kimia (chemical) atau elektrokimia (electrochemical) dengan lingkungannya. Korosi merupakan suatu masalah teknologi yang disebabkan oleh lingkungan alam dengan ditandai oleh perubahan energi dan fenomena ini mengakibatkan kerugian material sebagai bahan konstruksi. Pertukaran energi terjadi antara energi internal yang berasal dari material dan energi eksternal yang berada pada lingkungan material tersebut [5].

Under Deposot Corrosion atau korosi dibawah deposit yaitu korosi yang terjadi pada saat ada material lain yang menutupi permukaan baja atau metal. Deposit tersebut dapat berupa endapan tanah, lumpur, pasir, produk korosi, dan material padat lainnya. Material deposit dikelompokan menjadi 3 jenis yaitu deposit organik, deposit anorganik, dan "Schmoo" yang campuran antara deposit organik dan deposit anorganik. Kejadian korosi dibawah deposit dapat memicu terjadinya korosi lokal yaitu korosi celah dan korosi sumuran yang dapat menyebabkan kegagalan material logam [6].

\section{URAIAN PENELITIAN}

\section{A. Bahan Penelitian}

Material yang digunakan pada pengujian korosi antara lain:

- Pelat Baja A36

Pelat baja yang dilakukan pengujian korosi adalah baja karbon rendah grade A tipe A36 dengan komposisi kimia Carbon = 0,26\%; Silicon = 0,04\%; Phophorus $=0,04 \%$; Sulfur $=0,05 \%$; Manganese $=0,75 \%$ dan Copper $=0,2 \%$ [7]. Pelat baja berukuran $250 \times 100 \times 10 \mathrm{~mm}$ dipotong menjadi spesimen dengan ukuran 20 x 20 x 10 mm sebanyak 28 buah. Spesimen dipoles untuk menghaluskan permukaan spesimen dengan kertas amplas dari kekasaran 80 grit, 120 grit, 240 grit, 400 grit, dan 600 grit. Selanjutnya spesimen dicuci dengan air bersih dan disterilkan menggunakan larutan alkohol 96\%. Spesimen uji seperti Gambar 1 siap untuk digunakan.

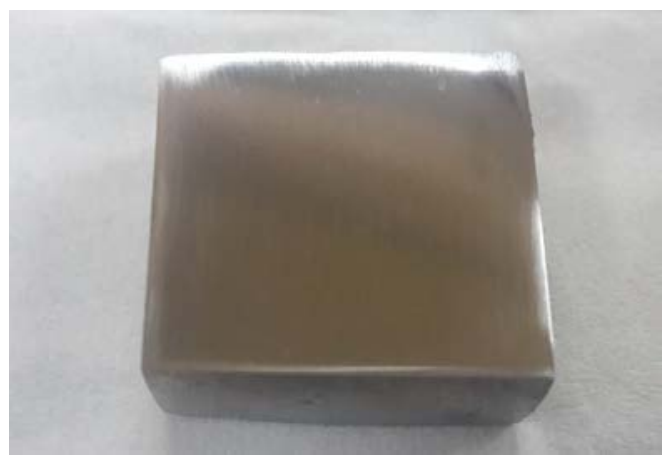

Gambar 1. Spesimen uji

\section{- Karat}

Karat yang digunakan sebagai bahan material deposit diambil dari pontoon foating dock dengan bentuk berupa kepingan. Karat tersebut dipreparasi menjadi butiran-butiran dengan cara dipukul dengan palu dan disaring untuk menyamakan ukuran butiran karat. Ukuran butiran karat antara $1 \mathrm{~mm}^{2}$ sampai dengan $4 \mathrm{~mm}^{2}$.

- Pasir sand blasting

Bahan material deposit pasir sand basting diambil dari tempat penyimpanan pasir yang dipreparasi dengan memisahkan pasir sand blasting dengan material lain dengan cara disaring.

\section{- Pembuatan material deposit karat sand blasting}

Karat sand basting seperti Gambar 2 digunakan sebagai materal deposit dimana nantinya diletakkan diatas permukaan spesimen. Untuk mengetahui pengaruh komposisi karat sand blasting terhadap laju korosi yang terjadi, maka dilakukan perbedaan komposisi antara pasir sand blasting dan karat yang sebelumnya telah disiapkan.

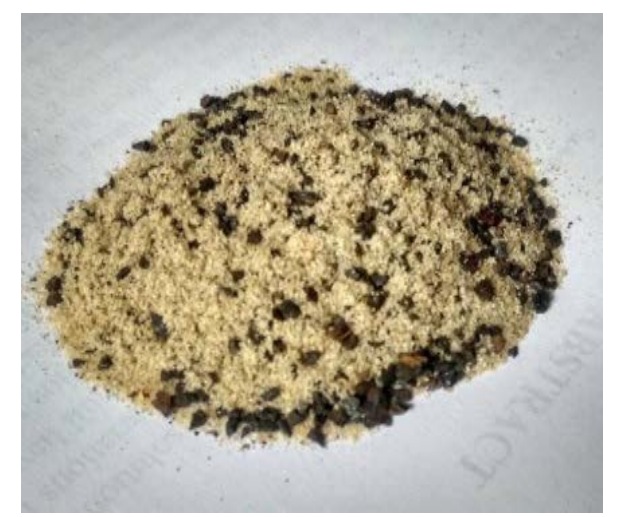

Gambar 2. Material deposit karat sand blasting

- Pembuatan material deposit karat sand blasting

Pengujian korosi ini dilakukan dengan variasi komposisi material deposit karat sand blasting, variasi ketebalan material deposit karat sand blasting, dan variasi permukaan yang tertutupi oleh material deposit karat sand blasting terhadap laju korosi pelat pontoon floating dock. Seperti pada Tabel 1 .

\section{B. Pengujian Argentometri}

Pengujian argentometri dilakukan untuk mengetahui kadar $\mathrm{NaCl}$ yang terkandung didalam material deposit karat sand blasting. Selain kadar $\mathrm{NaCl}$, juga dilakukan pengukuran kadar air di dalam material deposit . Hasil pengukuran kadar $\mathrm{NaCl}$ dalam material deposit yaitu sebesar 2,8\% dan kadar air sebesar 13,75\%.

Tabel 1

Variasi pengujian

\begin{tabular}{|c|c|c|c|c|c|}
\hline \multirow{2}{*}{ No } & \multirow{2}{*}{ Komposisi pasir sand blasting dan karat pada material deposit } & \multirow{2}{*}{ Tebal Material Deposit } & \multicolumn{3}{|c|}{ Bagian permukaan tertutupi material deposit } \\
\hline & & & $30 \%$ & $50 \%$ & $100 \%$ \\
\hline 1 & & $2 \mathrm{~cm}$ & $\sqrt{ }$ & $\sqrt{ }$ & $\sqrt{ }$ \\
\hline 2 & $(80 \%: 20 \%)$ & $4 \mathrm{~cm}$ & $\sqrt{ }$ & $\sqrt{ }$ & $\sqrt{ }$ \\
\hline 3 & & $6 \mathrm{~cm}$ & $\sqrt{ }$ & $\sqrt{ }$ & $\sqrt{ }$ \\
\hline 4 & & $2 \mathrm{~cm}$ & $\sqrt{ }$ & $\sqrt{ }$ & $\sqrt{ }$ \\
\hline 5 & $(70 \%: 30 \%)$ & $4 \mathrm{~cm}$ & $\sqrt{ }$ & $\sqrt{ }$ & $\sqrt{ }$ \\
\hline 6 & & $6 \mathrm{~cm}$ & $\sqrt{ }$ & $\sqrt{ }$ & $\sqrt{ }$ \\
\hline 7 & & $2 \mathrm{~cm}$ & $\sqrt{ }$ & $\sqrt{ }$ & $\sqrt{ }$ \\
\hline 8 & $(60 \%: 40 \%)$ & $4 \mathrm{~cm}$ & $\sqrt{ }$ & $\sqrt{ }$ & $\sqrt{ }$ \\
\hline 9 & & $6 \mathrm{~cm}$ & $\sqrt{ }$ & $\sqrt{ }$ & $\sqrt{ }$ \\
\hline 10 & Tanpa Deposit & & 1 & & \\
\hline
\end{tabular}




\section{Pengujian Korosi}

Pengujian korosi dilakukan dengan mengunakan metode elektrokimia dimana dalam sel korosi, spesimen uji ditambahkan material deposit yang terdiri dari pasir sand blasting dan karat di dalam larutan $\mathrm{NaCl} 3,5 \%$. Rangkaian pengujian korosi dapat dilihat pada Gambar 3. Langkah kerja pengujian korosi adalah sebagai berikut:

1. Spesimen uji dipasang kabel dan ditutupi dengan malam untuk menghindari kontak dengan larutan.

2. Spesimen dimasukkan kedalam wadah dan ditambahkan material deposit karat sand blasting diatas permukaan

3. Larutan $\mathrm{NaCl} 3,5 \%$ dimasukan kedalam wadah

4. Elektroda bantu dan elektroda referensi dimasukan kedalam larutan

5. Tiga elektroda disambungkan ke potensiostat dan dibuka software Corrtest kemudian memilih stable polarization dan memilih potentiodynamic.

6. Memasukan parameter pengujian ke dalam setup cell berupa range potential yaitu Initial E (V) -0.1 vs OCP dan Final $E$ (V) 0.1 vs OCP, luas permukaan spesimen 4 $\mathrm{cm}^{2}$, massa equivalent 27,9235 gram dan scan rate 5 $\mathrm{mV} / \mathrm{s}$.

7. Memilih menu running dan dimulai pengukuran rapat arus hingga didapatkan kurfa tafel

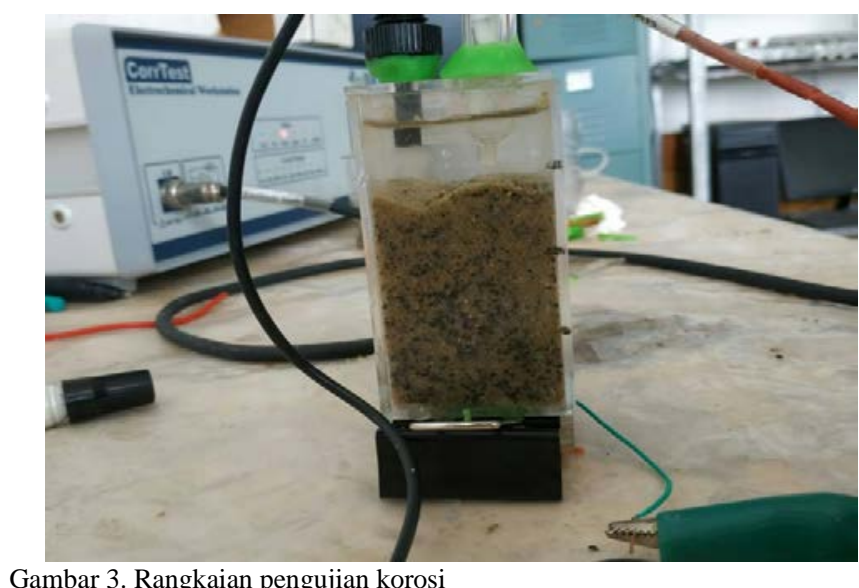

Dari data arus korosi (Icorr) yang diperoleh dari analisis kurva Tafel, kemudian dilakukan perhitungan laju korosi menggunakan persamaan hukum Faraday berikut [7]:

$$
\text { Laju korosi }=\frac{k a i}{n D}
$$

Keterangan:

Laju korosi dengan satuan mm/year atau mmpy

$a$ = berat atom logam yang terkorosi (gram / mol)

$\mathrm{i} \quad=$ kerapatan $\operatorname{arus}\left(\mu \mathrm{A} / \mathrm{cm}^{2}\right)$

$\mathrm{k} \quad=$ konstanta $(0,00327$ untuk satuan mmpy)

$\mathrm{n} \quad=$ elektron valensi

$\mathrm{D}=$ massa jenis logam terkorosi $\left(\mathrm{gram} / \mathrm{cm}^{3}\right.$ )

\section{HASIL DAN PEBAHASAN}

\section{A. Hasil Pengujian Korosi Spesimen tanpa Material Deposit}

Pengujian laju korosi pada spesimen tanpa material deposit sebagai benchmark terhadap pengujian laju korosi yang lain. Pengujian korosi ini dilakukan sebanyak 3 kali percobaan. Kurva tafel pada Gambar 4 menunjukan gambaran dari hasil pengujian untuk spesimen tanpa material deposit karat sand blasting. Gambar tersebut menunjukan tiga kurva tafel hubungan antara rapat arus dan potensial hasil pengujian spesimen tanpa material deposit. Kurva tafel diekstrapolasi untuk mendapatkan nilai potensial (Ecorr), nilai rapat arus (Icorr), dan nilai laju korosi (Corrosion rate).

Data hasil ekstrapolasi kurva tafel Tanpa Deposit 1 pada Tabel 2 didapatkan nilai potensial sebesar -0,593 V dan kerapatan arus sebesar 5,324 $\left(\mu \mathrm{A} / \mathrm{cm}^{2}\right)$. Perhitungan nilai laju korosi menggunakan persamaan hukum Faraday diperoleh nilai laju korosi sebesar 0,062 mmpy. Berbeda dengan hasil ekstrapolasi kurva tafel Tanpa Deposit 2, didapatkan besar potensial $-0,599 \mathrm{~V}$ dan kerapatan arus 5,430 $\left(\mu \mathrm{A} / \mathrm{cm}^{2}\right)$ dengan nilai laju korosi sebesar 0,063 mmpy. Sedangkan pada kurva tafel Tanpa Deposit 3, data hasil ekstrapolasi kurva yang didapatkan yaitu besar potensial $-0,603 \mathrm{~V}$ dan kerapatan arus 5,497 $\left(\mu \mathrm{A} / \mathrm{cm}^{2}\right)$ dengan nilai laju korosi 0,064 mmpy. Dari ketiga nilai laju korosi tersebut, didapatkan laju korosi rata-rata yaitu 0,063 mmpy.

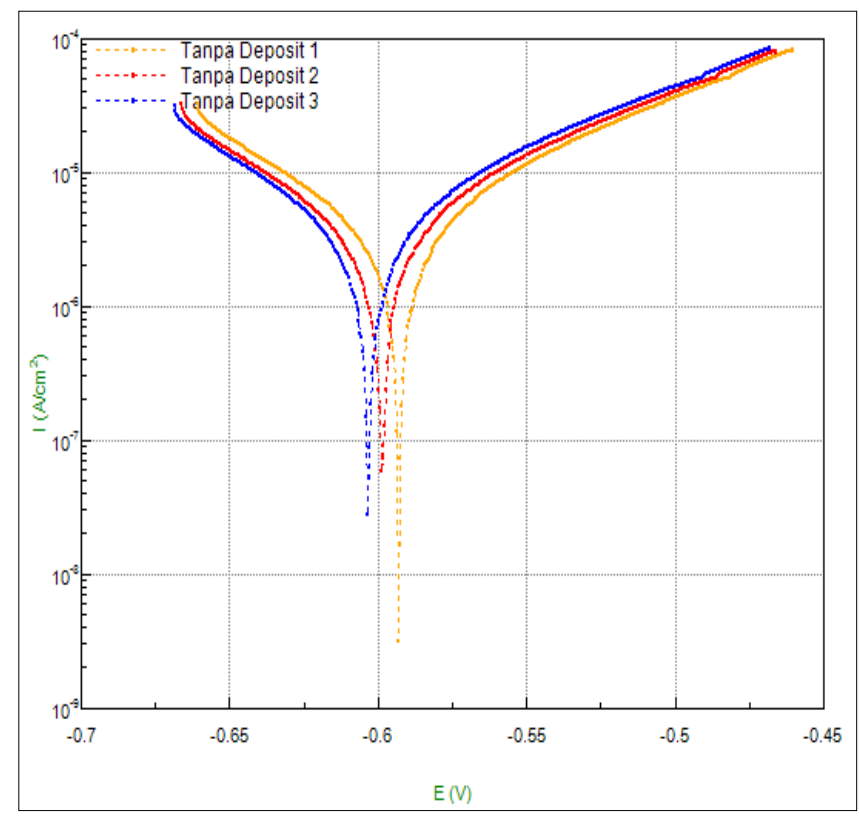

Gambar 4. Kurva tafel pengujian korosi specimen tanpa material deposit

Tabel 2.

Hasil pengujian korosi tanpa material deposit

\begin{tabular}{cccccc}
\hline \hline No & Percobaan & $\begin{array}{c}\text { Potensial } \\
(\mathbf{V})\end{array}$ & $\begin{array}{c}\text { Rapat Arus } \\
\left(\boldsymbol{\mu} \mathbf{A} / \mathbf{c m}^{\mathbf{2}}\right)\end{array}$ & $\begin{array}{c}\text { Laju Korosi } \\
(\mathbf{m m p y})\end{array}$ & $\begin{array}{c}\text { Laju korosi rata-rata } \\
(\mathbf{m m p y})\end{array}$ \\
\hline 1 & Tanpa Deposit 1 & $-0,593$ & 5,324 & 0,062 & 0,063 \\
2 & Tanpa Deposit 2 & $-0,599$ & 5,430 & 0,063 & 0,064 \\
3 & Tanpa Deposit 3 & $-0,603$ & 5,497 & & \\
\hline \hline
\end{tabular}




\section{B. Pengujian Korosi Spesimen dengan Komposisi Material Deposit Pasir Sand Blasting 80\% dan Karat 20\%}

Pengujian korosi pada spesimen yang tertutupi oleh material deposit karat sand blasting dengan komposisi pasir sand blasting $80 \%$ dan karat $20 \%$ dilakukan dengan menambahkan material deposit karat sand blasting diseluruh permukaan spesimen. Dari pengujian korosi ini, didapatkan nilai laju korosi rata-rata pada tebal material deposit $2 \mathrm{~cm}$ adalah sebesar 0,095 mmpy, tebal material deposit $4 \mathrm{~cm}$ didapatkan nilai laju korosi rata-rata sebesar 0,117 mmpy, dan tebal material deposit $6 \mathrm{~cm}$ didapatkan nilai laju korosi rata-rata sebesar $0,143 \mathrm{mmpy}$.

Nilai laju korosi yang diperoleh dari pengujian korosi spesimen dengan $50 \%$ permukaan tertutupi oleh material deposit karat sand blasting pada tebal material deposit $2 \mathrm{~cm}$ adalah sebesar 0,104 mmpy, pada tebal material deposit 4 cm diperoleh nilai laju korosi rata-rata sebesar 0,135 mmpy, dan pada tebal material deposit $6 \mathrm{~cm}$ didapatkan nilai laju korosi rata-rata sebesar 0,15 mmpy.

Pengujian korosi pada spesimen dengan 30\% permukaan tertutupi material deposit pada tebal material deposit $2 \mathrm{~cm}$ didapatkan nilai laju korosi rata-rata 0,109 mmpy, pada tebal material deposit $4 \mathrm{~cm}$ diperoleh nilai laju korosi ratarata sebesar 0,14 mmpy, dan tebal material deposit $6 \mathrm{~cm}$ didapatkan nilai laju korosi rata-rata sebesar 0,155 mmpy.

Grafik perbandingan nilai laju korosi spesimen dengan komposisi pasir sand blasting $80 \%$ dan karat $20 \%$ pada Gambar 5 menunjukan bahwa nilai laju korosi meningkat pada spesimen yang tertutupi oleh material deposit karat sand blasting dan nilai laju korosi meningkat dari ketebalan material deposit $2 \mathrm{~cm}, 4 \mathrm{~cm}$, dan $6 \mathrm{~cm}$. Nilai laju korosi tersebut lebih tinggi dari pada nilai laju korosi spesimen yang tidak tertutupi material deposit karat sand blasting.

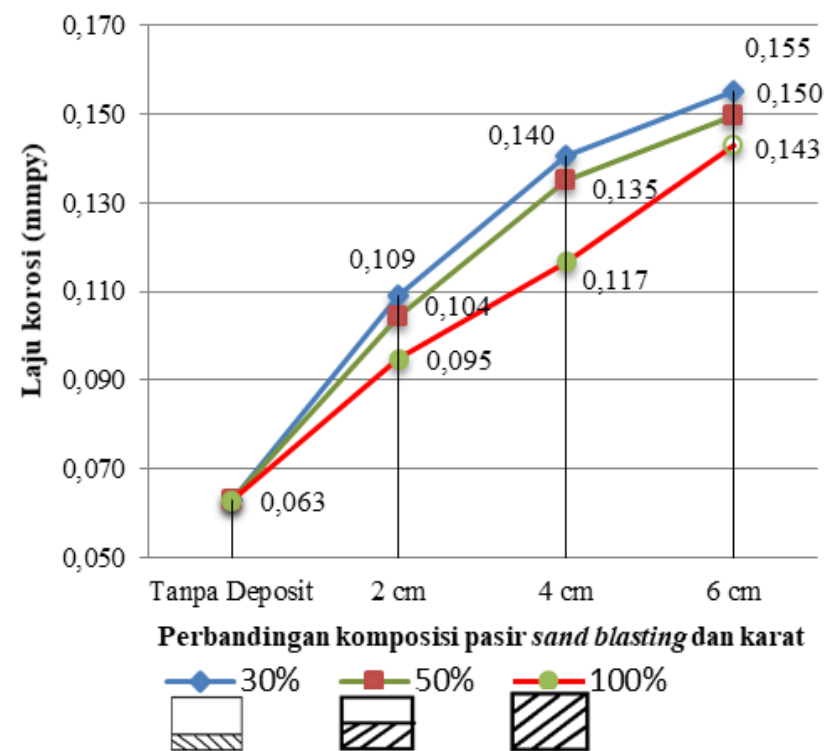

Gambar 5. Grafik perbandingan laju korosi spesimen dengan komposis pasir sand blasting $80 \%$ dan karat $20 \%$

Selain itu, spesimen yang hanya 30\% bagian permukaan tertutupi oleh material deposit mempunyai nilai laju korosi lebih tinggi dari pada nilai laju korosi spesimen yang permukaannya tertutupi $50 \%$ dan $100 \%$ oleh material deposit karat sand blasting. Hal ini menjelaskan bahwa material deposit diatas spesimen mempengaruhi tingkat ketahanan korosi dimana ketebalan material deposit yang lebih tinggi dan bagian permukaan yang tertutupi lebih sedikit oleh material deposit menyebabkan nilai laju korosi yang lebih besar.

\section{Pengujian Korosi Spesimen dengan Komposisi Material Deposit Pasir Sand Blasting 70\% dan Karat 30\%}

Pengujian korosi pada spesimen yang tertutupi oleh material deposit karat sand blasting dengan komposisi pasir sand blasting $70 \%$ dan karat 30\% dilakukan dengan menambahkan material deposit karat sand blasting diseluruh permukaan spesimen. Dari pengujian korosi ini, didapatkan nilai laju korosi rata-rata pada tebal material deposit $2 \mathrm{~cm}$ adalah sebesar 0,110 mmpy, tebal material deposit $4 \mathrm{~cm}$ didapatkan nilai laju korosi rata-rata sebesar 0,125, dan tebal material deposit $6 \mathrm{~cm}$ didapatkan nilai laju korosi rata-rata sebesar 0,159 mmpy.

Nilai laju korosi pada spesimen dengan material deposit menutupi 50\% permukaan spesimen pada tebal $2 \mathrm{~cm}$ adalah sebesar 0,117 mmpy, pada tebal $4 \mathrm{~cm}$ diperoleh nilai laju korosi rata-rata sebesar 0,165 mmpy, dan pada tebal $6 \mathrm{~cm}$ didapatkan nilai laju korosi rata-rata sebesar 0,197 mmpy.

Pengujian korosi pada spesimen dengan 30\% permukaan tertutupi material deposit pada tebal material deposit $2 \mathrm{~cm}$ didapatkan nilai laju korosi rata-rata 0,118 mmpy, pada tebal material deposit $4 \mathrm{~cm}$ diperoleh nilai laju korosi ratarata sebesar 0,165 mmpy, dan tebal material deposit $6 \mathrm{~cm}$ didapatkan nilai laju korosi rata-rata sebesar 0,250 mmpy.

Grafik laju korosi pada Gambar 6 menunjukan bahwa nilai laju korosi meningkat ketika spesimen diberikan material deposit karat sand blasting. Pada tebal material deposit $2 \mathrm{~cm}$, terjadi perbedaan nilai laju korosi yang kecil dari ketiga grafik tersebut. Tetapi tebal material deposit 4 $\mathrm{cm}$, nilai laju korosi dari ketiga garis grafik terjadi perbedaan nilai laju korosi yang besar sampai pada nilai laju korosi spesimen dengan tebal material deposit $6 \mathrm{~cm}$.

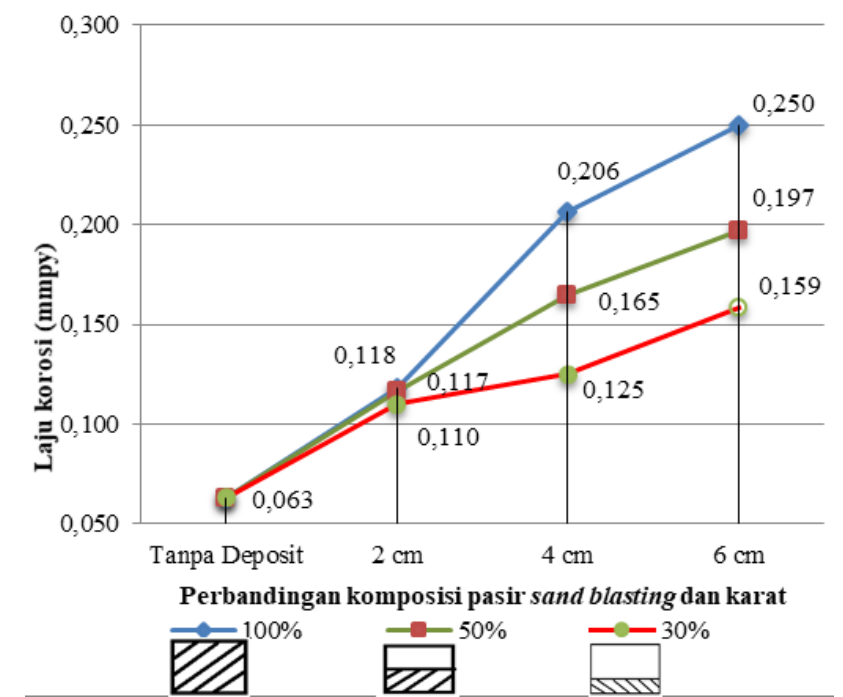

Gambar 6. Grafik perbandingan laju korosi spesimen dengan komposis pasir sand blasting $70 \%$ dan karat $30 \%$

Peningkatan nilai laju korosi berbeda-beda pada tiap-tiap pengujian, tetapi memiliki pola yang sama pada tiga garis tersebut dimana spesimen dengan material deposit karat sand blasting yang lebih tebal memiliki nilai laju korosi yang lebih tinggi. Selain itu, spesimen yang hanya 30\% bagian permukaan tertutupi oleh material deposit mempunyai nilai laju korosi lebih tinggi dari pada nilai laju korosi spesimen yang permukaannya tertutupi $50 \%$ dan 100\% oleh material deposit karat sand blasting. Diferensial aerasi yang tinggi antara pelat di bawah material deposit dan 
pelat di luar material deposit menyebabkan reaksi oksidasi yang tinggi terjadi pada pelat dibawah material deposit dan didaerah anoda tersebut mengalami peningkatan nilai $\mathrm{pH}$ sehingga nilai laju korosi semakin besar.

\section{Pengujian Korosi Spesimen dengan Komposisi Material} Deposit Pasir Sand Blasting 60\% dan Karat 40\%

Pengujian korosi pada spesimen yang tertutupi oleh material deposit karat sand blasting dengan komposisi pasir sand blasting $60 \%$ dan karat $40 \%$ dilakukan dengan menambahkan material deposit karat sand blasting diseluruh permukaan spesimen. Dari pengujian korosi ini, didapatkan nilai laju korosi rata-rata pada tebal material deposit $2 \mathrm{~cm}$ adalah sebesar 0,122 mmpy, tebal material deposit $4 \mathrm{~cm}$ didapatkan nilai laju korosi rata-rata sebesar 0,167 mmpy, dan tebal material deposit $6 \mathrm{~cm}$ didapatkan nilai laju korosi rata-rata sebesar 0,215 mmpy.

Nilai laju korosi pada spesimen dengan material deposit menutupi 50\% permukaan spesimen pada tebal $2 \mathrm{~cm}$ adalah sebesar 0,173 mmpy, pada tebal $4 \mathrm{~cm}$ diperoleh nilai laju korosi rata-rata sebesar 0,226 mmpy, dan pada tebal $6 \mathrm{~cm}$ didapatkan nilai laju korosi rata-rata sebesar 0,256 mmpy.

Pengujian korosi pada spesimen dengan 30\% permukaan tertutupi material deposit pada tebal material deposit $2 \mathrm{~cm}$ didapatkan nilai laju korosi rata-rata 0,203 mmpy, pada tebal material deposit $4 \mathrm{~cm}$ diperoleh nilai laju korosi ratarata sebesar 0,329 mmpy, dan tebal material deposit $6 \mathrm{~cm}$ didapatkan nilai laju korosi rata-rata sebesar 0,402 mmpy.

Grafik perbandingan nilai laju korosi pada Gambar 7 menunjukan nilai laju korosi yang lebih tinggi pada spesimen dengan penambahan material deposit karat sand blasting dari pada nilai laju korosi pada spesimen tanpa material deposit. Peningkatan nilai laju korosi berbeda-beda pada tiap-tiap spesimen, tetapi mempunyai pola yang sama dimana semakin tebal material deposit karat sand blasting yang menutupi permukaan spesimen maka nilai laju korosi yang terjadi semakin tinggi.

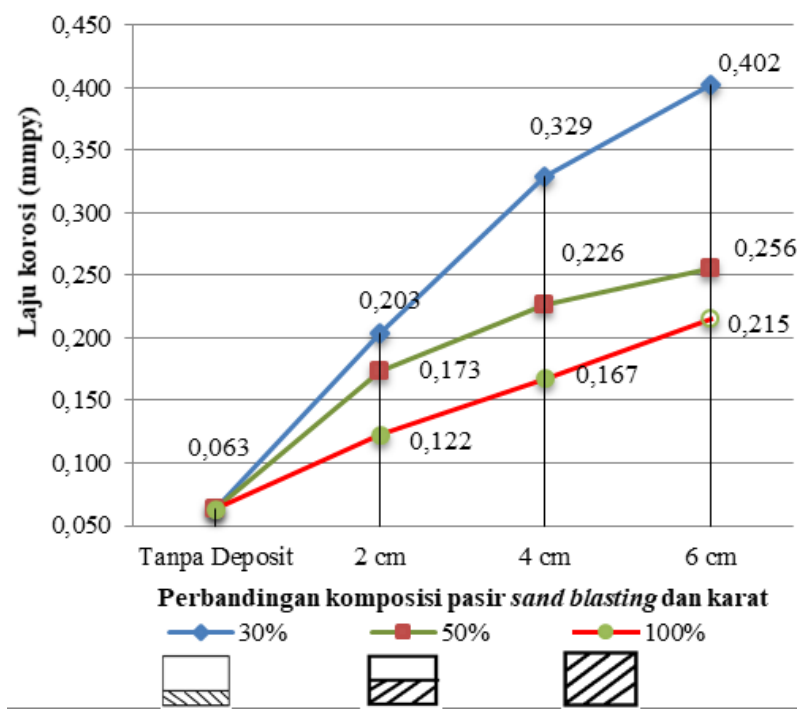

Gambar 7. Grafik perbandingan laju korosi spesimen dengan komposisi pasir sand blasting $60 \%$ dan karat $40 \%$

Spesimen dengan 30\% permukaan tertutupi oleh material deposit karat sand blasting mempunyai nilai laju korosi yang lebih besar dari pada spesimen dengan permukaan tertutupi $50 \%$. Selain itu, spesimen dengan permukaan tertutupi 50\% mempunyai nilai laju korosi yang lebih besar dari pada nilai laju korosi pada spesimen dengan permukaan tertutupi $100 \%$. Pengujian korosi ini, dengan komposisi material deposit pasir sand blasting 60\% dan karat $40 \%$ didapatkan nilai laju korosi yang lebih tinggi dari pada nilai laju korosi hasil pengujian korosi pada spesimen dengan komposisi pasir sand blasting 70\% dan karat 30\% dan pengujian korosi dengan komposisi pasir sand blasting $80 \%$ dan karat 20\%. Hal ini menunjukan bahwa nilai laju korosi dapat dipengaruhi oleh banyaknya kandungan karat didalam material deposit.

\section{E. Biaya Pergantian Pelat}

Perhitungan biaya yang dikeluarkan untuk melakukan pergantian pelat, terlebih dahulu menghitung berat pelat pontoon floating dock. Pergantian pelat yang akan dilakukan pada pontoon floating dock didasarkan bahwa pelat pontoon floating dock yang mengalami deformasi rawan terjadi genangan air dan tertutupi oleh material deposit berupa karat sand blasting sehingga pada daerah deformasi tersebut terbentuk material deposit karat sand blasting dalam kondisi basah yang dapat mempercepat laju korosi pelat pontoon floating dock di daerah deformasi. Pelat pontoon floating dock yang tertutupi material deposit karat sand blasting dalam kondisi basah karena adanya deformasi pelat yang diasumsikan $30 \%$ bagian pelat pontoon floating dock dimana pertimbangan ini didasarkan pada hasil survei lapangan. Berikut adalah perhitungan berat pelat ponton dari principal dimensions floating dock.

$\begin{array}{ll}\text { Lebar pontoon } & : 26,4 \mathrm{~m} \\ & : 138,52 \mathrm{~m}\end{array}$

Luas pelat pontoon : Panjang $\mathrm{x}$ Lebar

$$
\text { : 26,4 x 138,52 = 3656,928 } \mathrm{m}^{2}
$$

Luas pelat direplating : Luas pelat pontoon x $30 \%$

$$
\begin{aligned}
& \text { : } 3656,928 \times 0,3 \\
& : 1097,0784 \mathrm{~m}^{2}
\end{aligned}
$$

Volume : Luas pelat di replating $\mathrm{x}$ tebal pelat : $1097,0784 \times 0,01=10,97 \mathrm{~m}^{3}$

Berat pelat pengganti : Volume $\mathrm{x}$ massa jenis

$$
\begin{aligned}
& : 10,97 \mathrm{~m}^{3} \times 7850 \mathrm{~kg} / \mathrm{m}^{3} \\
& : 86114,5 \mathrm{~kg}
\end{aligned}
$$

Perhitungan biaya pergantian pelat adalah sebagai berikut:

Berat pelat pengganti $\quad: 86114,5 \mathrm{~kg}$

Biaya replating per $\mathrm{kg} \quad$ : Rp 28.000

Biaya replating pontoon : Berat pelat pengganti $\mathrm{x}$ biaya replating per $\mathrm{kg}$ : 86114,5 kg X Rp28.000

: Rp2.411.206.000,00

Dari perhitungan tersebut diketahui bahwa biaya yang dibutuhkan untuk melakukan pergantian pelat adalah sebesar Rp2.411.206.000,00.

\section{F. Analisis Kelayakan Investasi}

Dengan memperhatikan estimasi pendapatan galangan yang diperoleh dari floating dock, maka dapat disusun perhitungan Net Present Value (NPV) untuk mengetahui kelayakan investasi berupa pergantian pelat pontoon floating dock. Perhitungan NPV tersebut dilakukan dengan mengasumsikan penetapan tingkat suku bunga adalah suku bunga komersial pada bank pemerintah/swasta dalam rupiah yaitu sebesar $10 \%$ per tahun. Berikut adalah tabel perhitungan NPV pada investasi pergantian pelat yang disebabkan oleh korosi dari tumpukan karat sand blasting dengan perbandingan pasir sand blasting 60\% dan karat 40 $\%$, tebal $6 \mathrm{~cm}$, dan permukaan tertutupi $30 \%$ dimana periode pergantian pelat yaitu tiap 5,5 tahun sekali. 
Tabel 3

Perhitungan NPV pada tahun ke 5,5

\begin{tabular}{ccccc}
\hline \hline Tahun Ke- & Investasi awal (Rp) & Pendapatan & Discount Factor (10\%) & Present Value (Rp) \\
\hline 0 & 2.411 .206 .000 & & 1,00 & -2.411 .206 .000 \\
1 & & Rp1.644.192.000 & 0,93 & -916.486 .000 \\
2 & & Rp1.644.192.000 & 442.350 .364 \\
3 & Rp1.644.192.000 & 0,87 & 1.677 .656 .149 \\
4 & Rp1.644.192.000 & 0,76 & 2.800 .661 .408 \\
5 & Rp1.644.192.000 & 0,71 & 3.821 .575 .280 \\
5,5 & Rp1.644.192.000 & 0,67 & 4.285 .627 .040 \\
& & & 4.285 .627 .040 \\
\hline \hline
\end{tabular}

Pada Tabel 3 menunjukan bahwa investasi yang dilakukan setiap 5,5 tahun sekali berupa pergantian pelat pontoon flaoting dock sebesar Rp2.411.206.000 akan kembali pada tahun ke 3 dan memperoleh keuntungan pada tahun ke 6 sebesar Rp4.285.627.040. Dengan hasil perhitungan tersebut dapat disimpulkan bahwa pergantian pelat layak untuk dilakukan. Berikut adalah tabel perbandingan keuntungan yang diperoleh setelah dilakukan pergantian pelat pada tiap-tiap kondisi permukaan pelat pontoon floating dock.

Grafik perbandingan besar keuntungan floating dock pada Gambar 8 menunjukan bahwa keuntungan yang diperoleh dari floating dock dalam jangka waktu sekali pergantian pelat adalah sebesar Rp13.439.792.320,00 yaitu pada kondisi permukaan tidak tertutupi deposit karat sand blasting. Sedangkan pada kondisi permukaan pelat tertutupi oleh material deposit karat sand blasting, keuntungan yang diperoleh dari floating dock selama satu periode pergantian pelat adalah sebesar Rp4.285.627.040,00. Hal ini menunjukan bahwa pergantian pelat pada pontoon floating dock masih layak untuk dilakukan baik kerusakan yang disebabkan korosi akibat adanya karat sand blasting maupun dalam kondisi pelat pontoon floating dock bersih dari karat sand blasting karena masih diperoleh keuntungan dalam setiap jangka waktu pergantian pelat pontoon floating dock. Tetapi untuk mengoptimalkan keuntungan yang diperoleh dari floating dock, diharapkan untuk membersihkan pontoon floating dock dari material deposit karat sand blasting.

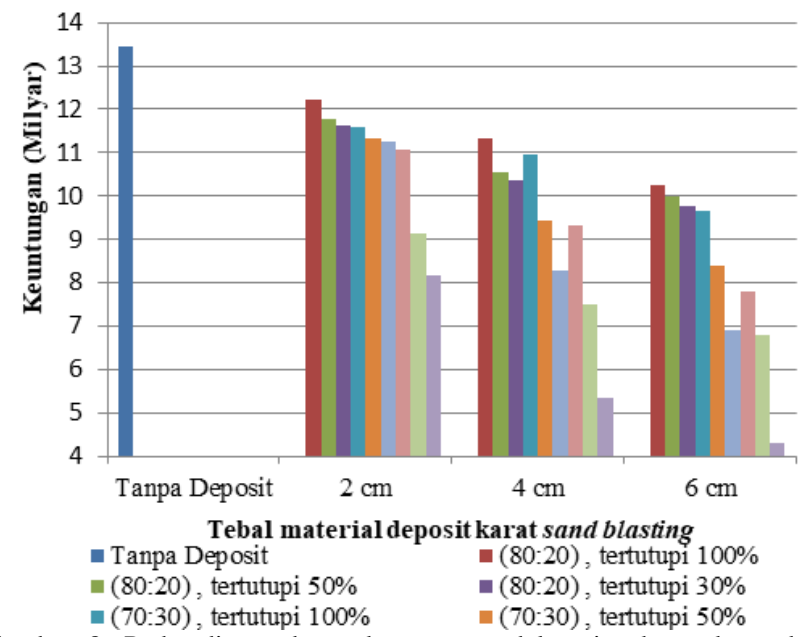

Gambar 8. Perbandingan besar keuntungan dalam jangka waktu sekali pergantian pelat

\section{KESIMPULAN}

Berdasarkan hasil uji argentometri, material deposit karat sand blasting mempunyai kadar $\mathrm{NaCl}$ sebesar 2,8\% dan kadar air 13,5\%. Kadar $\mathrm{NaCl}$ di dalam material deposit dipengaruhi oleh kadar air di dalam material deposit sehingga dalam pengujian korosi menggunakan kadar $\mathrm{NaCl}$ air laut yaitu kadar $\mathrm{NaCl} 3,5 \%$. Material deposit karat sand

blasting meningkatkan nilai laju korosi pada pelat pontoon floating dock, sesuai hasil pengujian laju korosi dimana pada permukaan yang tidak tertutupi oleh material deposit mempunyai nilai laju korosi sebesar 0,063 mmpy. Sedangkan pada permukaan yang tertutupi oleh material deposit karat sand blasting mempunyai nilai laju korosi yang lebih tinggi yaitu sebesar 0,402 mmpy dengan perbandingan komposisi pasir sand blasting dan karat adalah 60:40 \% dan tebal material deposit $6 \mathrm{~cm}$ yang permukaan tertutupi 30\% bagian oleh material deposit karat sand blasting.

Berdasarkan hasil uji korosi spesimen yang tertutupi material deposit dengan ketebalan $2 \mathrm{~cm}, 4 \mathrm{~cm}$, dan $6 \mathrm{~cm}$ dalam larutan $\mathrm{NaCl} 3,5 \%$ terjadi peningkatan nilai laju korosi. Semakin tebal material deposit karat sand blasting maka semakin tinggi nilai laju korosi yang terjadi. Nilai laju korosi spesimen yang permukaannya tertutupi 100\%, 50\%, dan $30 \%$ oleh material deposit karat sand blasting terjadi kenaikan nilai laju korosi. Semakin besar diferensial aerasi antara bagian permukaan yang tertutupi material deposit dan bagian permukaan yang tidak tertutupi material deposit karat sand blasting maka semakin besar nilai laju korosi yang terjadi. Nilai laju korosi spesimen yang tertutupi oleh material deposit karat sand blasting dengan perbandingan antara pasir sand blasting dan karat masing-masing yaitu (80\% : 20\%), (70\% : 30\%), dan (60\% : 40\%) mengalami peningkatan laju korosi. Semakin banyak kandungan karat didalam material deposit karat sand blasting maka semakin tinggi nilai laju korosinya.

Korosi yang disebabkan oleh karat sand blasting mengakibatkan keuntungan yang diperoleh dari floating dock menurun dimana keuntungan terendah yang diperoleh adalah sebesar Rp4.285.627.040,00. Sedangkan keuntungan yang diperoleh pada kondisi permukaan pontoon floating dock tidak tertutupi material deposit adalah sebesar Rp13.439.792.320,00.

\section{DAFTAR PUSTAKA}

[1] H. Supomo, Diktat teknologi produksi kapal lanjut. Institut Teknologi Sepuluh Nopember, 2017.

[2] H. S. dan T. W. P. A. Dwilaksono, "Analisis pengaruh salinitas air laut pada wet underwater welding terhadap laju korosi,” Institut Teknologi Sepuluh Nopember, 2013.

[3] J. Huang, "Mechanistic study of under deposit corrosion of mild steel in aqueous carbon dioxide solution,” Oiho University, 2013.

[4] B. B. and M. S. S. Hassani, J. Huang, A. C. Victor, "Inhibited under deposit CO2 corrosion: small particle silica sand and eicosane paraffin deposit,” Oiho University, 2000.

[5] M. Fontana, Corrosion engineering. San francisco: McGraw-Hil, 1987.

[6] B. B. and J. Moloney, "Under deposit corrosion," Oiho University, 2017.

[7] ASTM, "Standard practice for calculation of corrosion rates and related information from electrochemical measurements," vol. 3.2, pp. 102-89. 